\title{
THE UTILITY OF ELASTOSONOGRAPHY FOR ASSESSING SUBURETHRAL TISSUE ELASTICITY IN WOMEN WITH STRESS URINARY INCONTINENCE
}

\author{
Alptekin TOSUN ${ }^{1}$, Enis OZKAYA ${ }^{2}$, Eralp BASER ${ }^{3}$, Sertac ESIN $^{4}$ \\ 1 Giresun University School of Medicine, Department of Radiology, Giresun, Turkey \\ ${ }^{2}$ Giresun University School of Medicine, Department of Obstetrics and Gynecology, Giresun, Turkey \\ 3 Zekai Tahir Burak Women's Health Training and Research Hospital, \\ Department of Obstetrics and Gynecology, Ankara, Turkey \\ ${ }^{4}$ Etlik Zubeyde Hanim Women's Health Training and Research Hospital, \\ Department of Obstetrics and Gynecology, Ankara, Turkey
}

\begin{abstract}
SUMMARY
Objective: To determine clinical and diagnostic value of elastosonography (ES) in women with stress urinary incontinence (SUI).

Material and methods: Thirty subjects with SUI and 30 subjects without SUI were compared in terms of elastosonographic suburethral tissue elasticity. SUI and bladder neck hypermobility was determined by pad test, Q-tip and stress tests. Measurements points included under bladder (UB), subcutaneous fatty tissue (SC), and the urethra (U) points. Three indices were calculated using these measurements (UB/SC, U/SC and UB/U). The diagnostic value of ES indices were investigated using receiver operating characteristic (ROC) curve analyses.

Results: $E S U B / S C(A U C=0.962, P=0.001)$ and $U / S C(A U C=0.953, P=0.001)$ were significant predictors for stress test positivity. ES UB/SC $(A U C=0.883, P=0.001)$ and $U / S C(A U C=0.885, P=0.001)$ were significant predictors for pad test positivity. ES UB/SC (AUC=0.877, $P=0.001)$ and $U / S C(A U C=0.857, P=0.001)$ were significant predictors for $Q$ tip test positivity. In linear regression analysis, stress test positivity was significantly associated with the ES $U B / S C(R 2=0.84$, beta=0.369, $P=0.026)$ and $E S U / S C(R 2=0.84$, beta $=0.496, P=0.003)$.

Conclusion: Elastosonographic tissue elasticity determination is a promising tool in bladder neck hypermobility and SUI diagnosis, and may be used as an adjunctive method in selecting patients appropriate for stress urinary incontinence surgery.
\end{abstract}

Key words: elastosonography, stress urinary incontinence, urethral mobility

Journal of Turkish Society of Obstetrics and Gynecology, (J Turk Soc Obstet Gynecol), 2013; Vol: 10, Issue: 4, Pages: 207- 12

\section{STRES ÜRINER INKONTINANSI OLAN KADINLARDA SUBURETRAL DOKU ELASTIKIYYTININ DEĞERLENDİRILMESINDE ELASTOSONOGRAFINIIN YERI}

\section{ÖZET}

Amaç: Stres Üriner İnkontinansı (SÜI) olan kadın hastalarda Elastosonografinin (ES) klinik ve diagnostik değerini saptamak.

Gereç ve yöntemler: SÜİ tanısı olan 30 kadın ve şikayeti olmayan 30 kadın hastanın ES tetkikindeki suburetral doku elastikiyetleri karşılaştırıldı. Ped testi, Q-tip ve stres testleriyle SÜİ ve mesane boynunun hipermobilitesi teşhis edildi. ES tetkikinde mesane altı (MA) ve cilt altı (CA) dokular ile üretra (Ü) ölçüm alanları olarak değerlendirildi. MA/CA,

Address for Correspondence: Uzm. Dr. Enis Özkaya. Dr. Sami Ulus Kadın Doğum ve Çocuk Sağlı̆̆ Hastalıkları EAH, Ankara, Türkiye Phone: +90(505) 4742459

e-mail: enozkaya1979@gmail.com

Received: 23 May 2013, revised: 06 August 2013, accepted: 07 August 2013, online publication: 12. August 2013 
$\ddot{U} / C A$ ve $M A / \ddot{U}$ oranları hesaplandı. ES esnasında elde edilen bu oranların tanısal değeri ROC curve analizi ile incelendi. Bulgular: $M A / C A(A U C=0.962, P=0.001)$ ve $\ddot{U} / C A(A U C=0.953, P=0.001)$ stres test pozitifliği için anlamll prediktördür. $M A / C A(A U C=0.883, P=0.001)$ ve $\ddot{U} / C A(A U C=0.885, P=0.001)$ Ped testi için anlamll prediktördür. $M A / C A(A U C=0.877, P=0.001)$ ve $\ddot{U} / C A(A U C=0.857, P=0.001) Q$ tip test pozitifliği için anlaml prediktördür. Lineer regresyon analizinde Stres test pozitifliği $M A / C A(R 2=0.84$, beta $=0.369, P=0.026)$ ve $\ddot{U} / C A(R 2=0.84$, beta $=0.496, P=0.003)$ ile istatistiksel olarak anlamlı birliktelik göstermektedir.

Sonuç: ES ile doku elastikiyetinin karakterizasyonu, SÜİ ve mesane boynu hipermobilitesinin teşhisinde umut verici bir teknik olup, SÜİ cerrahisi için hasta seçiminde ek metot olarak kullanılabilir.

Anahtar kelimeler: elastosonografi, mesane boynu hipermobilitesi, stres üriner inkontinans

Türk Jinekoloji ve Obstetrik Derneği Dergisi, (J Turk Soc Obstet Gynecol), 2013; Cilt: 10, Sayl: 4, Sayfa: $207-12$

\section{INTRODUCTION}

Urinary incontinence (UI) is a common symptom in women, mostly occurring in the elderly ${ }^{(1)}$. Alterations in urinary bladder capacity, as well as urine storage and emptying functions may contribute to UI development. Childbirth, aging or other medical conditions may also impose detrimental effects against urinary continence. Pathophysiologic changes underlying stress urinary incontinence (SUI) has been previously investigated in several studies $(2,3)$. In these studies, it was well documented that a sudden increase in intraabdominal and/or intravesical pressure, as well as decreased urethral sphincter tonus or bladder neck support leads to SUI. Among these factors, bladder neck hypermobility $(\mathrm{BNH})$ is generally considered one of the most important determinants. Fascial weakness and increased elasticity of the surrounding tissues play an important role in $\mathrm{BNH}$.

Diagnosing stress urinary incontinence depends mainly on patient history and findings from simple clinical maneuvers ${ }^{(4)}$. Although pad test, Q-tip test and stress tests are widely used for SUI investigation, they are time and labor consuming(4-6). In this study, we aimed to assess the utility of elastosonography (ES), which is a non-invasive ultrasonographic technique for evaluation of suburethral tissue elasticity, in women with SUI.

\section{MATERIALS AND METHODS}

\section{Patient Selection}

The study was conducted between August 2012 and January 2013 at the radiology and obstetrics\& gynecology departments of Giresun University Medical
School Hospital, Giresun, Turkey. Scientific and ethical approval was received from the institutional review board. All participants gave written informed consent. Thirty consecutive women with diagnosis of SUI that was confirmed by positivity in either one of the stress, pad and Q tip tests were included in the study. All patients had at least one childbirth experience. The control group comprised 30 similar aged women with negative test results for SUI.

\section{Clinical Tests for SUI}

Pad test was used, is it is the gold standard diagnostic method in SUI. We also assessed SUI with stress test and Q-tip tests, to address BNH.

Pad test: After emptying with a transurethral foley catheter, the bladder was filled with $300 \mathrm{cc}$ of sterile saline. The catheter was then removed and the patient was directed to standing position after placement of a standard perineal pad. Following intra-abdominal pressure increasing exercises (coughing, bearing down, deep knee bending, jumping and walking), the pad weight was measured within an hour. The net weight of urine was calculated by subtraction of dry pad weight form the measured pad weight. Net urine weight greater than 2 gr was considered a positive test result for SUI. Q-tip test: A small lubricated cotton swab was introduced into the urethra up to the level of bladder neck. Valsalva maneuver was performed by the patient with the cotton swab in place. BNH was diagnosed in cases with a rotation angle greater than $30^{\circ}$ from the initial position of the swab.

Stress test: With the patient in standing position, she was instructed to cough or bear down (Valsalva maneuver) vigorously during physician observation. Presence of urine leakage was considered a positive stress test. 


\section{Elastosonography (ES) technique}

All participants in the SUI and control groups underwent ES at the radiology department. All ES examinations were performed by a single radiologist. Transvaginal sonographic imaging was undertaken with a 4-13 MHz linear probe (Esaote, MyLab60, Geneva, Italy), prior to emptying the bladder. The surrounding proximal suburethral tissue elasticity was evaluated in a standard manner. The strain ratio of the surrounding suburethral tissue to subcutaneous fatty tissue, suburethral tissue and urethra were measured in the axial plane. Real time tissue elasticity images with a color mapped translucent appearance overlapping the gray scale were obtained. Colors ranged from green to red, which represented relative elasticity degrees of the observed tissue. Red signal represented the tissues with low elasticity, whereas green signals indicated tissues with high elasticity. Distance of tissue movement after application of pressure was measured with ES. After the four to five compression-decompression cycles with an appropriate spring, we selected four region of interest (ROI) from the surrounding fatty tissue: suburethral tissue, proximal urethra and the subcutaneous fatty tissue. The green spring was a realtime feedback of correct performance of the strain image acquisition. The elasticity measurements were performed in several points of the surrounding suburethral tissue: under bladder (UB), the urethral tissue (U) and the softest area for the subcutaneous fatty tissue (SC) were selected in 3-5 mm distance. The software automatically calculated the strain ratio between ROIs. Used strain ratio indices were; UB/SC, $\mathrm{U} / \mathrm{SC}$ and $\mathrm{UB} / \mathrm{U}$.

\section{Statistical Analysis}

The statistical analyses were performed using the Statistic Package for Social Sciences (ver. 11.0; SPSS Inc., Chicago, IL). For group comparisons independent samples $t$ test was used for continious variables while chi-square test was used compare categorical variables. Correlation analysis was used to calculate degree of associations and linear regression analysis was used to determine adjusted associations. ROC was used to determine the predictive value of the tests. $P$ value smaller than 0.05 was accepted as statistically significant.

\section{RESULTS}

Mean age, gravidity, parity of the study population were $49.7 \pm 7.1$ years, $3.9 \pm 1.2,2.9 \pm 1.1$ respectively. Stress test was positive in all 30 women with SUI, while pad test was positive in 22 women. Q tip test was positive in 21 cases. Age, gravidity and parity were similar between groups with negative and positive stress test $(p>0.05)$. Qtip test angle was significantly higher in group with stress test positivity $(14.3 \mathrm{vs} 40, \mathrm{p}<0.05)$. Age gravidity and parity were similar between groups with negative and positive pad test ( $p>0.05)$. Q tip test angle was significantly higher in group with pad test positivity ( $20 \mathrm{vs} 39, \mathrm{p}<0.05$ ). Age, gravidity and parity were similar between groups with negative and positive Q-tip test ( $p>0.05)$. ES UB and U/SC were significantly higher in group with tests positivity $(\mathrm{p}<0.05)$ (Image 1-2). Comparison of groups defined according to the results of three different tests were shown in Table I.

Table I: Comparison of some clinical and demographic characteristics of groups with positive and negative results for three different tests.

\begin{tabular}{|c|c|c|c|c|c|c|c|c|c|c|c|c|c|c|c|}
\hline & $\begin{array}{l}\text { QT } \\
\text { TES }\end{array}$ & ${ }^{\mathrm{N}}$ & Mean & $\mathrm{SD}$ & $\mathrm{p}$ & PT & $\mathrm{N}$ & Mean & SD & $\mathrm{p}$ & ST & $\mathrm{N}$ & Mean & SD & $\mathrm{p}$ \\
\hline \multirow[t]{2}{*}{ Age } & $\mathbf{N}$ & 39 & 49.8 & 7.4 & & $\mathbf{N}$ & 38 & 50.3 & 7.2 & & $\mathbf{N}$ & 30 & 50.7 & 7.1 & \\
\hline & $\mathbf{P}$ & 21 & 49.2 & 6.5 & NS & $\mathbf{P}$ & 22 & 48.4 & 6.8 & NS & $\mathbf{P}$ & 30 & 48.6 & 7.02 & NS \\
\hline \multirow[t]{2}{*}{$\mathbf{G}$} & $\mathbf{N}$ & 39 & 4.05 & 1.2 & & $\mathbf{N}$ & 38 & 3.8 & 1.3 & & $\mathbf{N}$ & 30 & 4.06 & 1.3 & \\
\hline & $\mathbf{P}$ & 21 & 3.8 & 1.2 & NS & $\mathbf{P}$ & 22 & 4.1 & 1.05 & NS & $\mathbf{P}$ & 30 & 3.9 & 1.1 & NS \\
\hline \multirow[t]{2}{*}{$\mathbf{P}$} & $\mathbf{N}$ & 39 & 2.9 & 1.07 & & $\mathbf{N}$ & 38 & 2.7 & 1.1 & & $\mathbf{N}$ & 30 & 2.9 & 1.09 & \\
\hline & $\mathbf{P}$ & 21 & 2.8 & 1.1 & NS & $\mathbf{P}$ & 22 & 3.09 & 0.9 & NS & $\mathbf{P}$ & 30 & 2.8 & 1.08 & NS \\
\hline \multirow[t]{2}{*}{ UB/SC } & $\mathbf{N}$ & 39 & 4.6 & 1.4 & & $\mathbf{N}$ & 38 & 4.5 & 1.3 & & $\mathbf{N}$ & 30 & 4.01 & 0.7 & \\
\hline & $\mathbf{P}$ & 21 & 6.8 & 1.05 & $<0.001$ & $\mathbf{P}$ & 22 & 6.8 & 1.2 & $<0.001$ & $\mathbf{P}$ & 30 & 6.7 & 1.2 & $<0.001$ \\
\hline \multirow[t]{2}{*}{$\mathbf{U B} / \mathbf{U}$} & $\mathbf{N}$ & 39 & 1.1 & 0.1 & & $\mathbf{N}$ & 38 & 1.1 & 0.1 & & $\mathbf{N}$ & 30 & 1.1 & 0.1 & \\
\hline & $\mathbf{P}$ & 21 & 1.1 & 0.1 & NS & $\mathbf{P}$ & 22 & 1.08 & 0.1 & NS & $\mathbf{P}$ & 30 & 1.1 & 0.1 & NS \\
\hline \multirow[t]{2}{*}{ U/SC } & $\mathbf{N}$ & 39 & 4.3 & 1.9 & & $\mathbf{N}$ & 38 & 4.02 & 1.6 & & $\mathbf{N}$ & 30 & 3.4 & 0.9 & \\
\hline & $\mathbf{P}$ & 21 & 6.9 & 1.4 & $<0.001$ & $\mathbf{P}$ & 22 & 7.3 & 1.2 & $<0.001$ & $\mathbf{P}$ & 30 & 7.06 & 1.5 & $<0.001$ \\
\hline
\end{tabular}

QT: Q tip test, SD: Standard deviation, PT: Pad test, ST: Stress test, G: Gravidity, P: Parity, UB/SC: Elastosonogtaphy of under bladder to subcutenous tissue, UB/U: Elastosonogtaphy of under bladder to urethra, U/SC: Elastosonogtaphy of urethra to subcutenous tissue, N: Negative, P: Positive, NS: Not significant. 
Image 1: Elastosonographic image of patient with stress urinary incontinence.

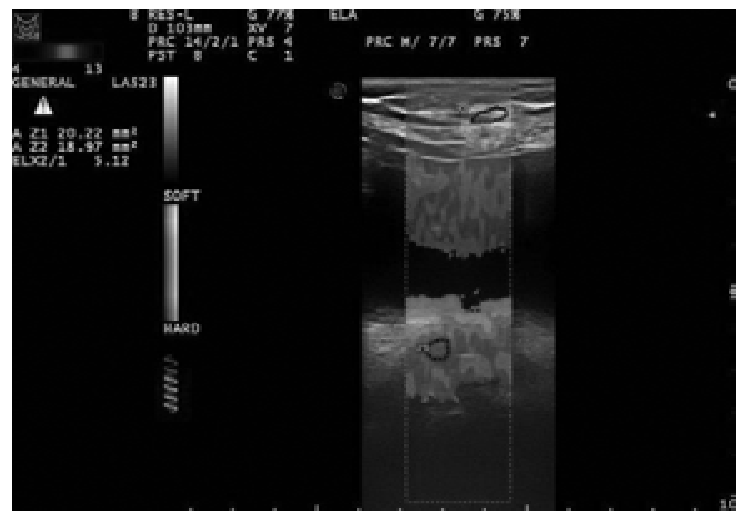

Image 2: Elastosonography of patient without stress urinary incontinence.

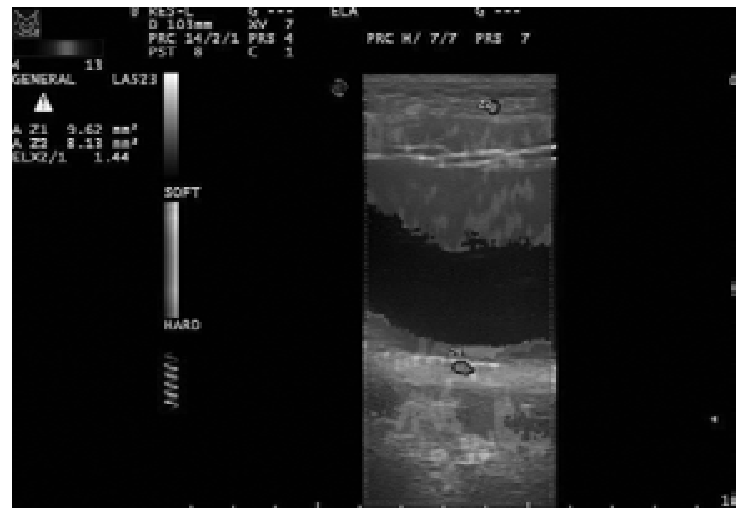

Mean ES strain ratios of UB/SC,UB/U and U/SC were $5.4 \pm 1.7$ (range 3.3-9.1), 1.1 \pm 0.2 (range 1.01-1.5), $5.2 \pm 2.2$ (range 1.2-8.9) respectively. ES UB/SC was positively correlated with stress test $(\mathrm{r}=0.813, \mathrm{p}=0.001)$, pad test $(\mathrm{r}=0.649, \mathrm{p}=0.001)$ and $\mathrm{Q}$ tip tests $(\mathrm{r}=0.633$, $\mathrm{p}=0.001)$. ES U/SC was also positively correlated with stress test $(r=0.794, p=0.001)$, pad test $(r=0.649$, $\mathrm{p}=0.001)$ and $\mathrm{Q}$ tip test results $(\mathrm{r}=0.638, \mathrm{p}=0.001)$. ES UB/U was negatively correlated with parity $(r=$ $0.273, \mathrm{P}=0.035)$. There was no correlation between the gravidity, parity, route of delivery and the stress, $\mathrm{Q}$ tip and pad tests $(\mathrm{p}<0.05)$.

On ROC curve analysis, ES UB/SC $(\mathrm{AUC}=0.962$, $\mathrm{p}=0.001)$ and $\mathrm{U} / \mathrm{SC}(\mathrm{AUC}=0.953, \mathrm{p}=0.001)$ were significant predictors for stress test positivity (Figure 1). $\mathrm{UB} / \mathrm{SC}(\mathrm{AUC}=0.883, \mathrm{p}=0.001)$ and $\mathrm{U} / \mathrm{SC}$ (AUC $=0.885, p=0.001)$ were significant predictors for pad test positivity (Figure 2$) . \mathrm{UB} / \mathrm{SC}(\mathrm{AUC}=0.877$, $\mathrm{p}=0.001)$ and $\mathrm{U} / \mathrm{SC}(\mathrm{AUC}=0.857, \mathrm{p}=0.001)$ were significant predictors for Q-tip test positivity (Figure $3)$.
Figure 1: Receiver Operating Characteristic (ROC) Curve for ES in predicting a positive stress test.

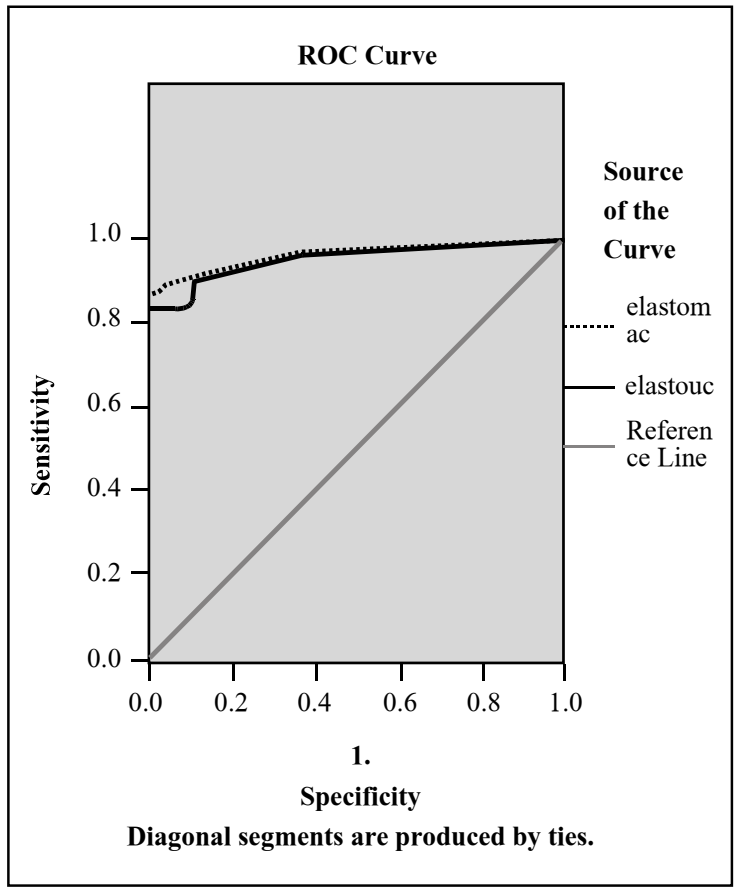

Figure 2: Receiver Operating Characteristic (ROC) Curve for ES in predicting a positive pad test.

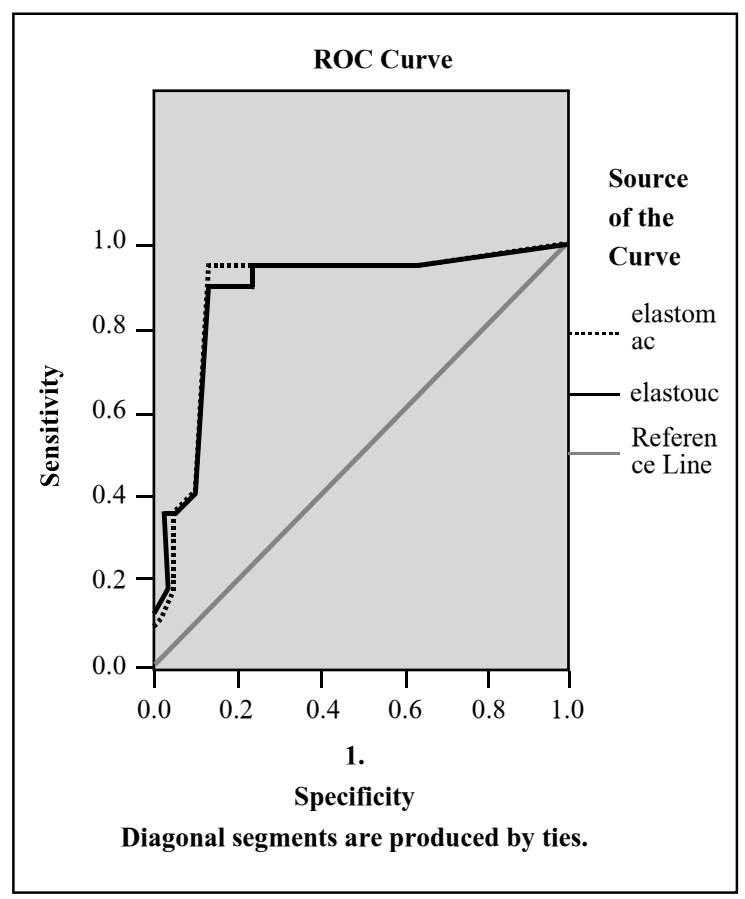


Figure 3: Receiver Operating Characteristic (ROC) Curve for ES in predicting a positive Q-tip test.

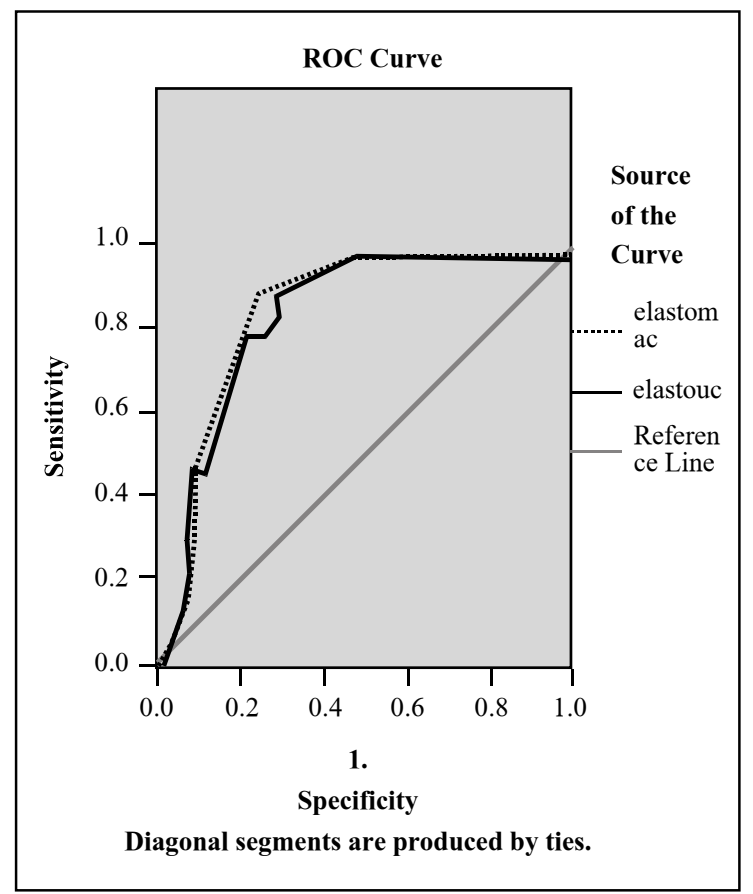

In linear regression analysis, stress test positivity was significantly associated with the $\mathrm{ES} \mathrm{UB} / \mathrm{SC}\left(\mathrm{R}^{2}=0.84\right.$, beta $=0.369, \mathrm{p}=0.026)$ and $\mathrm{ES} \mathrm{U} / \mathrm{SC}\left(\mathrm{R}^{2}=0.84\right.$, beta $=0.496, p=0.003$ ).

\section{DISCUSSION}

In this study, we aimed to assess the utility of a recently introduced sonographic technique in patients with SUI. We found that ES has diagnostic value in detecting $\mathrm{BNH}$, and is a promising method for identifying patients that would benefit from bladder neck stabilization.

It is well established that weakness in suburethral tissue support causes BNH, which may ultimately result in SUI. Although the degree of BNH can be assessed by several clinical methods, fullness of the bladder, patient position and catheterization may influence measurements (7-9). Using these techniques, small variations in methodology may result in substantial differences in nulliparous women ${ }^{(10,11)}$.

Measurement of bladder neck descent (BND) was previously reported to be a useful technique in SUI evaluation $^{(12,13)}$. In this technique, measurements of bladder neck position are performed at rest and during maximal Valsalva maneuver(14). Pathogenesis of increased BND is generally considered multifactorial. Vaginal delivery is probably the most significant determinant of BND in multiparas ${ }^{(15,16)}$. Although the reproducibility of BND measurement was reported to be acceptable, there is still no consensus on "normal" values ${ }^{(17)}$. Mid-urethral mobility was also demonstrated to be an important etiologic factor for SUI(18). Several studies claimed that preoperative assessment of midurethral mobility could predict the treatment success after bladder neck supporting surgical procedures $(19,20)$. From this point of view, we hypothesized that elastosonographic evaluation of suburethral tissue may provide important information regarding weakness and elasticity of tissue support under the urethrovesical angle. In our study, Q-tip test was used to determine degree of BNH. Strikingly, ES indices were significantly positive correlated with Q-tip results. Considering its pathophysiology, SUI accompanied by $\mathrm{BNH}$ is generally treated by surgical methods which are aimed towards stabilization and supporting of the bladder $\operatorname{neck}^{(21)}$.

In cases with SUI, ultrasonography (US) is generally used for postvoidal determination of residual volume, which may also contribute to development of SUI(4). Both bladder neck and segmental urethral mobility can be determined by sonography(22). Urodynamic ultrasonography is a noninvasive imaging method for the investigation of urinary system function, however it is highly complicated to perform and to interpret. Measurements are dependent on calculation of orthogonal system $\mathrm{x}, \mathrm{y}$ coordinates. This technique is highly operator dependent and has significant intraobserver and interobserver variability. A recently published study claimed that visualization of periurethral structures by $3 \mathrm{D}$ endovaginal ultrasonography in midsagittal plane is not associated with stress urinary incontinence status ${ }^{(23)}$. In our study, we introduced a simple measurement method, which can be used by clinicians with average experience in ultrasonography. Apart from its ease of application, we found that ES indices (UB/SC, UB/U and $\mathrm{U} / \mathrm{SC}$ ) were sensitive markers for SUI.

In summary, compared with the clinical tests current used in diagnosis of $\mathrm{BNH}$, we believe that $\mathrm{ES}$ is easier to perform and is also more objective. Our study suggests that ES is a simple, fast and non-invasive imaging technique in the diagnosis of SUI(24). Tissue 
elasticity determination using ES may be a promising tool in selecting appropriate for candidates for surgery. ES may even yield future treatments using stem cells to support the weakened tissue under the bladder neck (25). Thus, further research is indicated to assess the value of ES in women with SUI.

\section{REFERENCES}

1. Gibbs CF, Johnson TM, 2nd, Ouslander JG. Office management of geriatric urinary incontinence. Am J Med. 2007 Mart;120(3): 211-20

2. Staskin D, Tubaro A, Norton PA, Ashton-Miller JA. Mechanisms of continence and surgical cure in female and male SUI: surgical research initiatives. Neurourol Urodyn. 2011 Jun;30(5):704- 7.

3. Luber KM. The definition, prevalence, and risk factors for stress urinary incontinence. Rev Urol. 2004;6 Suppl 3: S39

4. Norton P, Brubaker L. Urinary incontinence in women. Lancet. 2006 Jan 7;367(9504):57-67.

5. Price DM, Noblett K. Comparison of the cough stress test and 24-h pad test in the assessment of stress urinary incontinence. Int Urogynecol J. 2012 Apr;23(4):429-33.

6. Fleischmann N, Flisser AJ, Blaivas JG, Panagopoulos G. Sphincteric urinary incontinence: relationship of vesical leak point pressure, urethral mobility and severity of incontinence. J Urol. 2003 Mar;169(3):999-1002.

7. Dietz HP. Ultrasound imaging of the pelvic floor. Part I: twodimensional aspects. Ultrasound Obstet Gynecol. 2004 Jan; 23(1):80-92.

8. Dietz HP, Wilson PD. The influence of bladder volume on the position and mobility of the urethrovesical junction. Int Urogynecol J Pelvic Floor Dysfunct. 1999;10(1):3-6.

9. Schaer GN, Koechli OR, Schuessler B, Haller U. Perineal ultrasound: determination of reliable examination procedures. Ultrasound Obstet Gynecol. 1996 May;7(5):347-52.

10. Peschers UM, Fanger G, Schaer GN, Vodusek DB, DeLancey JO, Schuessler B. Bladder neck mobility in continent nulliparous women. BJOG. 2001 Mar;108(3):320- 4.

11. Brandt FT, Albuquerque CD, Lorenzato FR, Amaral FJ. Perineal assessment of urethrovesical junction mobility in young continent females. Int Urogynecol J Pelvic Floor Dysfunct. 2000;11(1):18- 22.

12. Jundt K, Scheer I, Schiessl B, Karl K, Friese K, Peschers UM
Incontinence, bladder neck mobility, and sphincter ruptures in primiparous women. Eur J Med Res. 2010 Jun 28;15(6): 246-52.

13. King JK, Freeman RM. Is antenatal bladder neck mobility a risk factor for postpartum stress incontinence? Br J Obstet Gynaecol. 1998 Dec;105(12):1300-7.

14. Dietz HP. Pelvic floor ultrasound in incontinence: what's in it for the surgeon? Int Urogynecol J. 2011 Sep;22(9):1085-97.

15. Dietz HP, Bennett MJ. The effect of childbirth on pelvic organ mobility. Obstet Gynecol. 2003 Aug;102(2):223-8.

16. Peschers U, Schaer G, Anthuber C, Delancey JO, Schuessler B. Changes in vesical neck mobility following vaginal delivery. Obstet Gynecol. 1996 Dec;88(6):1001-6.

17. Dietz HP, Eldridge A, Grace M, Clarke B. Pelvic organ descent in young nulligravid women. Am J Obstet Gynecol. 2004 Jul; 191(1):95-9.

18. Pirpiris A, Shek KL, Dietz HP. Urethral mobility and urinary incontinence. Ultrasound Obstet Gynecol. 2010 Oct;36(4): 507-11.

19. Guerette NL, Bena JF, Davila GW. Transobturator slings for stress incontinence: using urodynamic parameters to predict outcomes. Int Urogynecol J Pelvic Floor Dysfunct. 2008 Jan; 19(1):97-102.

20. Chantarasorn V, Shek K, Dietz H. Predictors of failure after Monarc suburethral sling. Int Urogynecol J Pelvic Floor Dysfunct. 2009;20:s332-3.

21. Dietz HP, Wilson PD. The 'iris effect': how two-dimensional and three-dimensional ultrasound can help us understand antiincontinence procedures. Ultrasound Obstet Gynecol. 2004 Mar; 23(3):267-71.

22. Shek KL, Dietz HP. The urethral motion profile: a novel method to evaluate urethral support and mobility. Aust N Z J Obstet Gynaecol. 2008 Jun;48(3):337-42.

23. Rostaminia G, White DE, Quiroz LH, Shobeiri SA. Visualization of periurethral structures by $3 \mathrm{D}$ endovaginal ultrasonography in midsagittal plane is not associated with stress urinary incontinence status. Int Urogynecol J. 2013 Jul;24(7):1145-50.

24. Masata J, Martan A, Svabik K, Drahoradova P, Pavlikova M. Ultrasound imaging of the lower urinary tract after successful tension-free vaginal tape (TVT) procedure. Ultrasound Obstet Gynecol. 2006 Aug;28(2):221-8.

25. Surcel C, Savu C, Chibelean C, Iordache A, Mirvald C, Sinescu I. Comparative analysis of different surgical procedures for female stress urinary incontinence. Is stem cell implantation the future? Rom J Morphol Embryol. 2012;53(1):151-4. 